\title{
Primary School Teachers' Use of ICT for Administration and Management
}

\author{
Ian Selwood \\ The University of Birmingham, School of Education, Edgbaston, Birmingham, UK \\ I.D.Selwood@Bham.AC.UK
}

\begin{abstract}
This paper reports on the findings of the baseline study "ICT Test Bed Project" in England as they relate to Primary School Teachers' use of ICT for administration and management. Data is presented that illustrates primary teachers' attitudes towards ICT and its use for administration and management; their access to ICT and satisfaction with this; their views on training and the type of training they have received; and their use of ICT for administration and management including frequency of use, and factors that influence their use. Even though primary teachers are generally positive about ICT and its ability to support their administrative and management duties, the findings point to low levels of use of ICT for administration and management. Reasons for this lack of use relate to lack of quality training and the availability of time and quality ICT resources.
\end{abstract}

Key words: ICT, Primary Teachers, Administration, Management, Workload.

\section{INTRODUCTION}

The publication "Information and communications technology in UK schools: An independent enquiry" by the Stevenson Committee (1997) highlighted not only the potential uses of ICT in UK schools but concluded that the state of ICT in UK schools was primitive and not improving and that it should be a national priority to increase the use of ICT in schools. Since 1997 there have been several government initiatives in the UK to encourage the use of ICT in schools, notably the implementation of the National Grid for Learning (NGfL) (DfEE, 1997); the lottery funded (New Opportunities Fund (NOF)) scheme to provide ICT training or re-training for all 500,000 
practising teachers and school librarians (TTA, 1998); and Curriculum Online (DfES, 2002). The "ICT Test Bed Project" (DfES, 2003) is one of the UK governments' latest ICT initiatives and combines large-scale investments in ICT hardware, software and support, with a commitment to professional development and collaboration between participating schools and colleges, over a four-year period. The emphasis of the project is placed upon: "Using ICT to:

- Raise standards and performance, concentrating in particular on school improvement and raising the quality of teaching and learning.

- Enable more effective leadership and management in schools.

- Help teachers to concentrate their time on core task of teaching.

- Enable more effective collaboration between schools and with their local colleges.

- Provide wider learning opportunities to pupils, their families and the wider community in a home environment." (DfES, 2003)

To enable progress to be monitored, a baseline study of the 28 schools involved in the project ( 5 secondary, 1 special school and 22 primary schools) was undertaken by a team from The University of Birmingham led by Professor Hywel Thomas. The schools in the "Test Bed Project" were chosen by the DfES after LEAs had submitted details of clusters of schools that they felt could work effectively together, to allow the exploration of the potential of ICT to support greater collaboration between schools.

The baseline study took place between $18^{\text {th }}$ October and $6^{\text {th }}$ November 2002 when all of the "Test Bed Schools" were visited, and all teaching and support staff completed a very comprehensive questionnaire, which achieved a response rate of $91 \%$. Additionally, during the school visits a cross-section of staff (Headteacher, member of Senior Management team, middle manager, class teachers and teaching assistants) were interviewed. A great deal of the data collected relates to the use of ICT in supporting teaching and learning. However, this paper presents only the data that relates to primary teachers' use of ICT for administrative and management purposes. Research on teacher workloads is extensive but there is relatively little on the role ICT can play in reducing teacher workloads (Becta, 2003), and there is also very little research on the use of ITEM by classroom teachers (Selwood, Smith and Wishart, 2001). The results presented in this paper may, in some small way, redress this situation by illustrating the current position in English Primary Schools. 


\section{RESULTS}

\subsection{Primary Teachers' Views on the Use of ICT}

Table 1. Primary teachers' views on the use of ICT

\begin{tabular}{|c|c|c|c|c|c|c|}
\hline & VS.Dis $^{1}$ & S.Dis & Dis & Agree & S.Agree & V.S.Agree \\
\hline I find it easy to use ICT & $2 \%$ & $5 \%$ & $27 \%$ & $39 \%$ & $19 \%$ & $8 \%$ \\
\hline $\begin{array}{l}\text { Working with ICT makes me } \\
\text { nervous }\end{array}$ & $17 \%$ & $14 \%$ & $36 \%$ & $26 \%$ & $6 \%$ & $2 \%$ \\
\hline ICT makes work less enjoyable & $16 \%$ & $25 \%$ & $47 \%$ & $11 \%$ & $2 \%$ & $0 \%$ \\
\hline Working with ICT is boring & $24 \%$ & $25 \%$ & $46 \%$ & $5 \%$ & $0 \%$ & $0 \%$ \\
\hline $\begin{array}{l}\text { ICT makes school work more } \\
\text { enjoyable }\end{array}$ & $0 \%$ & $1 \%$ & $20 \%$ & $57 \%$ & $13 \%$ & $9 \%$ \\
\hline $\begin{array}{l}\text { Using ICT will reduce my } \\
\text { workload }\end{array}$ & $1 \%$ & $4 \%$ & $28 \%$ & $50 \%$ & $11 \%$ & $6 \%$ \\
\hline $\begin{array}{l}\text { Using ICT makes me more } \\
\text { productive }\end{array}$ & $1 \%$ & $2 \%$ & $26 \%$ & $58 \%$ & $8 \%$ & $5 \%$ \\
\hline $\begin{array}{l}\text { I work better when I work with } \\
\text { ICT }\end{array}$ & $2 \%$ & $5 \%$ & $47 \%$ & $34 \%$ & $7 \%$ & $5 \%$ \\
\hline $\begin{array}{l}\text { ICT is used effectively by my } \\
\text { school to manage resources }\end{array}$ & $2 \%$ & $5 \%$ & $41 \%$ & $43 \%$ & $5 \%$ & $5 \%$ \\
\hline $\begin{array}{l}\text { ICT is used effectively by my } \\
\text { school in decision making }\end{array}$ & $2 \%$ & $6 \%$ & $54 \%$ & $33 \%$ & $5 \%$ & $1 \%$ \\
\hline
\end{tabular}

Attitudes towards ICT are important if its potential is to be utilised. Table 1 shows the opinions of primary teachers with respect to their use of ICT and the use of ICT in their schools. Confidence in using ICT is relatively high with about two thirds of teachers agreeing with the statement " $I$ find it easy to use ICT' and this corresponds with one-third agreeing with the statement that ICT can make them nervous. Only $13 \%$ of teachers felt ICT made work less enjoyable and 5\% that working with ICT was boring. Whereas $79 \%$ felt ICT made work more enjoyable. With respect to primary teachers' views on the effect of ICT on workload, over two-thirds felt that ICT will reduce their workload and $71 \%$ that ICT made them more productive. However, only $46 \%$ felt that they actually worked better when they work with ICT. This apparent contradiction may relate to primary teachers' perception that they need more training (see 2.4). The final two rows of Table 1 differ from the others in that they show primary teachers perceptions of how the school uses ICT rather than how they personally use ICT. Just over half (53\%) felt that ICT was used effectively by their school to manage resources, but only $39 \%$ felt that ICT was used effectively by their school in decision making.

1 In all tables VS.Dis=Very Strongly Disagree, S.Dis=Strongly Disagree, Dis=Disagree, S. Agree $=$ Strongly Agree, VS. Agree=Very Strongly Agree 


\subsection{Access to ICT}

If teachers are to use ICT for administration and management then access to quality hardware and software are important factors. It is also apparent that with the very limited non-contact time that primary teachers have in the UK, that access to ICT outside of their school is also an important factor. Teachers were therefore asked about where they could access computers; their satisfaction with the quality of the hardware and software in their school; and what provision their schools made in supporting their access to ICT in their homes.

\subsubsection{Where can primary teachers use a computer?}

Table 2. Places where primary teachers can use a computer

\begin{tabular}{llllllll}
\hline & 0 & 1 & 2 & 3 & 4 & 5 & 6 \\
\hline This School & $2 \%$ & $0 \%$ & $0 \%$ & $0 \%$ & $2 \%$ & $29 \%$ & $68 \%$ \\
Another School & $58 \%$ & $6 \%$ & $19 \%$ & $1 \%$ & $2 \%$ & $11 \%$ & $4 \%$ \\
Other Work Place & $67 \%$ & $8 \%$ & $13 \%$ & $1 \%$ & $2 \%$ & $8 \%$ & $2 \%$ \\
Home & $4 \%$ & $9 \%$ & $0 \%$ & $0 \%$ & $4 \%$ & $8 \%$ & $76 \%$ \\
Public Library & $45 \%$ & $2 \%$ & $2 \%$ & $2 \%$ & $26 \%$ & $14 \%$ & $10 \%$ \\
Internet Café & $54 \%$ & $3 \%$ & $6 \%$ & $5 \%$ & $9 \%$ & $9 \%$ & $14 \%$ \\
Community Centre & $70 \%$ & $12 \%$ & $4 \%$ & $1 \%$ & $6 \%$ & $5 \%$ & $2 \%$ \\
\hline
\end{tabular}

Table 3. Key to Table 2

\begin{tabular}{|l|l|c|l|}
\hline 0 & No response & 1 & There is no computer here \\
\hline 2 & $\begin{array}{l}\text { I am not allowed to use a computer } \\
\text { here }\end{array}$ & 3 & $\begin{array}{l}\text { There is a computer here, but it costs too } \\
\text { much for me to use it }\end{array}$ \\
\hline 4 & $\begin{array}{l}\text { There is a computer here but it is } \\
\text { usually too busy }\end{array}$ & 5 & I can usually use a computer here \\
\hline 6 & $\begin{array}{l}\text { I can use a computer here whenever } \\
\text { I want }\end{array}$ & & \\
\hline
\end{tabular}

Analysing the places where teachers can readily access computers it is apparent that the main place of use "whenever they want" or where they can "usually" get access is at home (84\%) and at school (97\%). Use of computers at other locations is relatively rare with the public library being the next highest and scoring only $24 \%$. However with the high levels of access at school and at home, lack of use in other locations is not surprising.

\subsubsection{Primary teachers' satisfaction with hardware and software at school}

Sixty-nine percent of primary teachers, either agreed, strongly agreed or very strongly agreed that the school's computers were suitable to their needs. 


\section{Management}

With reference to other hardware and software the number of positive responses were lower $59 \%$ and $54 \%$ respectively. However, in relation to this paper these responses may be somewhat misleading as they may relate to the suitability of hardware and software for supporting teaching and learning, as the context of this question was not specified. On the other hand, it could be argued that, if the hardware and software is not suitable for teaching and learning this will add to teachers' workload.

Table 4. Primary teachers' satisfaction with hardware and software at school

\begin{tabular}{lllllll}
\hline & VS.Dis & S.Dis & Dis & Agree & S.Agree & V.S.Agree \\
\hline $\begin{array}{l}\text { The computers in school are } \\
\text { suitable to my needs }\end{array}$ & $5 \%$ & $6 \%$ & $20 \%$ & $54 \%$ & $9 \%$ & $6 \%$ \\
$\begin{array}{l}\text { The other hardware (e.g. printers, } \\
\text { scanners) is suitable to my needs }\end{array}$ & $5 \%$ & $9 \%$ & $29 \%$ & $46 \%$ & $9 \%$ & $4 \%$ \\
$\begin{array}{l}\text { The software in school is suitable } \\
\text { to my needs }\end{array}$ & $5 \%$ & $9 \%$ & $32 \%$ & $45 \%$ & $5 \%$ & $4 \%$ \\
\hline
\end{tabular}

\subsubsection{Schools' ICT hardware and software for use at home}

Table 5. Schools' ICT hardware and software for use at home

\begin{tabular}{lc}
\hline & Agreeing \\
\hline The school provides me with a laptop for use at home & $40 \%$ \\
The school provides me with a desktop computer for use at home & $0 \%$ \\
The school provides me with additional computer hardware for use at home (e.g. & $5 \%$ \\
printer, scanner or digital camera) & \\
The school provides licensed software for use at home & $12 \%$ \\
The school pays internet charges at home & $0 \%$ \\
I can access school e-mail at home & $37 \%$ \\
I can access my school computer and transfer files electronically to my home & $8 \%$ \\
computer & \\
I can access the school website and staff resources from home & $21 \%$ \\
\hline
\end{tabular}

In 2.2.1, it was reported that there was high access to computers at home. However, across all primary schools, responses to the statements in this section show limited levels of school-supported access to ICT hardware and software at home. The highest level of support was $40 \%$ of primary teachers having access at home to a laptop computer provided by the school, though according to interviews the laptop was often shared by two or more teachers. Provision of a desktop computer, for use at home, across all schools was negligible. Similarly, there was very limited home provision of other hardware and licensed software. No teachers reported assistance in meeting the costs of home Internet use. Only $8 \%$ of primary teachers could transfer files electronically between school and home and only $21 \%$ could "access the school website and staff resources from home". However, $37 \%$ of primary teachers reported the ability to access school e-mail from home. 
In the open-ended questions at the end of the questionnaire, primary teachers commonly raised the issue that they needed better access to hardware and software, and that the hardware and software needs to be fit for use.

\subsection{Primary Teachers' Knowledge/Confidence in ICT}

Table 6. Primary teachers' knowledge/confidence in ICT

\begin{tabular}{|c|c|c|c|c|c|c|}
\hline & $\begin{array}{l}\text { I've } \\
\text { never } \\
\text { used } \\
\text { this }\end{array}$ & $\begin{array}{l}\text { I need } \\
\text { more } \\
\text { training } \\
\text { to learn } \\
\text { the } \\
\text { basics }\end{array}$ & $\begin{array}{l}\text { I need } \\
\text { to } \\
\text { improve } \\
\text { my } \\
\text { skills }\end{array}$ & $\begin{array}{l}\text { I have } \\
\text { most } \\
\text { of the } \\
\text { skills I } \\
\text { need }\end{array}$ & $\begin{array}{l}\text { My skills } \\
\text { are } \\
\text { sufficient } \\
\text { for my } \\
\text { needs }\end{array}$ & $\begin{array}{l}\text { I am } \\
\text { good } \\
\text { enough } \\
\text { to } \\
\text { teach } \\
\text { this to } \\
\text { others }\end{array}$ \\
\hline Word processor & $0 \%$ & $4 \%$ & $15 \%$ & $16 \%$ & $26 \%$ & $39 \%$ \\
\hline Database & $9 \%$ & $17 \%$ & $32 \%$ & $18 \%$ & $17 \%$ & $7 \%$ \\
\hline Spreadsheet & $15 \%$ & $15 \%$ & $29 \%$ & $17 \%$ & $13 \%$ & $11 \%$ \\
\hline Presentation software & $23 \%$ & $16 \%$ & $29 \%$ & $11 \%$ & $11 \%$ & $11 \%$ \\
\hline Desktop publishing & $22 \%$ & $17 \%$ & $27 \%$ & $15 \%$ & $10 \%$ & $10 \%$ \\
\hline $\begin{array}{l}\text { Administration and } \\
\text { management software }\end{array}$ & $42 \%$ & $17 \%$ & $22 \%$ & $10 \%$ & $6 \%$ & $2 \%$ \\
\hline School intranet & $27 \%$ & $10 \%$ & $18 \%$ & $20 \%$ & $14 \%$ & $12 \%$ \\
\hline Search the internet / WWW & $2 \%$ & $7 \%$ & $16 \%$ & $22 \%$ & $21 \%$ & $32 \%$ \\
\hline Create web pages & $56 \%$ & $16 \%$ & $16 \%$ & $5 \%$ & $4 \%$ & $4 \%$ \\
\hline $\begin{array}{l}\text { Internet discussion boards } \\
\text { or chat rooms }\end{array}$ & $51 \%$ & $8 \%$ & $16 \%$ & $11 \%$ & $9 \%$ & $5 \%$ \\
\hline E-mail & $6 \%$ & $9 \%$ & $15 \%$ & $17 \%$ & $26 \%$ & $27 \%$ \\
\hline $\begin{array}{l}\text { Peripheral hardware e.g. } \\
\text { scanner, printer }\end{array}$ & $6 \%$ & $15 \%$ & $24 \%$ & $20 \%$ & $23 \%$ & $12 \%$ \\
\hline $\begin{array}{l}\text { Personal digital assistant } \\
\text { (PDA) }\end{array}$ & $80 \%$ & $6 \%$ & $8 \%$ & $2 \%$ & $2 \%$ & $0 \%$ \\
\hline Video conferencing & $80 \%$ & $10 \%$ & $9 \%$ & $1 \%$ & $0 \%$ & $0 \%$ \\
\hline $\begin{array}{l}\text { Authoring own multimedia } \\
\text { or web resources }\end{array}$ & $77 \%$ & $10 \%$ & $9 \%$ & $3 \%$ & $1 \%$ & $1 \%$ \\
\hline
\end{tabular}

In commenting on this section an initial benchmark of the percentage of teachers who respond positively to any of the three statements 'I have most of the skills I need', 'My skills are sufficient for my needs' and 'I am good enough to teach this to others' is used. Across all primary schools, four applications attract agreement from $50 \%$ or more: word processing (81\%), the Internet $(75 \%)$, e-mail $(70 \%)$ and peripheral hardware $(55 \%)$. Furthermore, an examination of Table 6 reveals that more than $20 \%$ of primary teachers responded that 'I've never used this' for 9 of the 15 items. 


\subsection{Training in ICT}

\subsubsection{Primary teachers' views on training}

Table 7. Primary teachers' views on training

\begin{tabular}{lllllll}
\hline & VS.Dis & S.Dis & Dis & Agree & S.Agree & V.S.Agree \\
\hline $\begin{array}{l}\text { I have improved my ICT skills in } \\
\text { the last 12 months }\end{array}$ & $0 \%$ & $2 \%$ & $7 \%$ & $53 \%$ & $26 \%$ & $12 \%$ \\
$\begin{array}{l}\text { The training I have received in } \\
\text { using ICT in the last } 12 \text { months }\end{array}$ & $10 \%$ & $9 \%$ & $28 \%$ & $39 \%$ & $10 \%$ & $4 \%$ \\
$\begin{array}{l}\text { has been good } \\
\text { I do not need to learn to use ICT }\end{array}$ & $34 \%$ & $23 \%$ & $39 \%$ & $3 \%$ & $1 \%$ & $0 \%$ \\
\hline
\end{tabular}

The great majority (91\%) of primary teachers felt that they had improved their ICT skills in the 12 months prior to completing the questionnaire. However, their opinions on the quality of the training they had received over the same period was less positive with only just over half (54\%) agreeing that the training was good. Nonetheless, $96 \%$ disagreed with the statement "I do not need to learn to use ICT", implying they wanted further training.

\subsection{Types of Training}

It should be noted that more than one response is possible to each of the statements in Table 8, although in practice, few teachers made multiple entries. The low level of what might be termed formal training as compared with 'no training' and 'help from a friend or colleague', other than a school ICT expert, is worrying. In summary, for 14 of the 15 items, $20 \%$ or more of teachers report having received no training or help; for 7 of these items, $50 \%$ or more teachers report having received no training or help. Examining the items where primary teachers report the higher levels of more formal training only two (word processing at $64 \%$ and spreadsheets at $50 \%$ ) were identified by 50 per cent or more teachers. Databases (48\%), Internet (43\%) and e-mail (34\%) were the next highest. 
Table 8. Types of training

\begin{tabular}{|c|c|c|c|c|c|c|}
\hline & $\begin{array}{l}\text { No } \\
\text { training } \\
\text { or help }\end{array}$ & $\begin{array}{l}\text { Help from } \\
\text { a friend or } \\
\text { colleague }\end{array}$ & $\begin{array}{l}\text { Help } \\
\text { from a } \\
\text { school } \\
\text { ICT } \\
\text { expert }\end{array}$ & $\begin{array}{l}\text { An ICT } \\
\text { course } \\
\text { taught } \\
\text { by your } \\
\text { school } \\
\text { ICT } \\
\text { expert }\end{array}$ & $\begin{array}{l}\text { An ICT } \\
\text { course } \\
\text { taught by } \\
\text { an expert } \\
\text { outside } \\
\text { school }\end{array}$ & $\begin{array}{l}\text { Part of a } \\
\text { nationally } \\
\text { recognised } \\
\text { qualification }\end{array}$ \\
\hline Word processor & $17 \%$ & $32 \%$ & $11 \%$ & $6 \%$ & $29 \%$ & $18 \%$ \\
\hline Database & $34 \%$ & $23 \%$ & $9 \%$ & $4 \%$ & $20 \%$ & $15 \%$ \\
\hline Spreadsheet & $36 \%$ & $18 \%$ & $8 \%$ & $4 \%$ & $22 \%$ & $16 \%$ \\
\hline $\begin{array}{l}\text { Presentation } \\
\text { Software }\end{array}$ & $48 \%$ & $20 \%$ & $6 \%$ & $3 \%$ & $14 \%$ & $8 \%$ \\
\hline DTP & $56 \%$ & $20 \%$ & $4 \%$ & $3 \%$ & $11 \%$ & $4 \%$ \\
\hline $\begin{array}{l}\text { Administration } \\
\text { and } \\
\text { management } \\
\text { software }\end{array}$ & $68 \%$ & $10 \%$ & $5 \%$ & $2 \%$ & $12 \%$ & $3 \%$ \\
\hline School intranet & $46 \%$ & $17 \%$ & $18 \%$ & $6 \%$ & $9 \%$ & $0 \%$ \\
\hline $\begin{array}{l}\text { Search the } \\
\text { internet }\end{array}$ & $20 \%$ & $39 \%$ & $12 \%$ & $9 \%$ & $17 \%$ & $5 \%$ \\
\hline $\begin{array}{l}\text { Create web } \\
\text { pages }\end{array}$ & $75 \%$ & $7 \%$ & $2 \%$ & $2 \%$ & $10 \%$ & $1 \%$ \\
\hline $\begin{array}{l}\text { Internet } \\
\text { discussion } \\
\text { boards or chat } \\
\text { rooms }\end{array}$ & $77 \%$ & $13 \%$ & $2 \%$ & $1 \%$ & $4 \%$ & $1 \%$ \\
\hline E-mail & $26 \%$ & $42 \%$ & $11 \%$ & $8 \%$ & $12 \%$ & $3 \%$ \\
\hline $\begin{array}{l}\text { Peripheral } \\
\text { hardware }\end{array}$ & $35 \%$ & $42 \%$ & $12 \%$ & $4 \%$ & $5 \%$ & $2 \%$ \\
\hline $\begin{array}{l}\text { Personal digital } \\
\text { assistant (PDA) }\end{array}$ & $97 \%$ & $1 \%$ & $1 \%$ & $0 \%$ & $1 \%$ & $0 \%$ \\
\hline $\begin{array}{l}\text { Video } \\
\text { conferencing }\end{array}$ & $87 \%$ & $2 \%$ & $1 \%$ & $0 \%$ & $4 \%$ & $0 \%$ \\
\hline $\begin{array}{l}\text { Authoring own } \\
\text { multimedia or } \\
\text { web resources }\end{array}$ & $84 \%$ & $2 \%$ & $1 \%$ & $0 \%$ & $6 \%$ & $0 \%$ \\
\hline
\end{tabular}

The interviews revealed that there is a need for more training and time to practice what has been learned in formal training sessions. However, NOF ICT training is generally regarded as having been ineffective overall, but four of the twenty-two primary schools reported positive experiences of NOF training. LEA training was generally regarded as effective, but there were some comments regarding variability in quality and responsiveness to needs. In-house formal training is a strong feature of ICT training, and it is generally regarded as very effective. However, the interviews supported the questionnaire data that primary schools rely a lot on in-house self-taught approaches based on learning by doing the job supported by manuals. This is a response to necessity and while it meets an immediate need staff are 
Management

concerned that this approach can only do so much and that opportunities for learning could be lost.

At the end of the questionnaire open-ended questions were asked regarding issues that most concerned respondents regarding their use of ICT, and they were also asked to give examples of what they needed to further develop their role through use of ICT. In response to both questions, the most common response was need for more and better training for staff and need for time to practice what they have learnt. Primary teachers also felt there was a need to improve use of ICT in administration and management of teaching and learning e.g. access to and analysis of pupil progress data

\subsection{Use of ICT}

\subsubsection{Frequency of use of ICT for management and administration}

Table 9. Frequency of use of ICT for management and administration

\begin{tabular}{|c|c|c|c|c|c|c|}
\hline & $\begin{array}{l}\text { Don't } \\
\text { use }\end{array}$ & $\begin{array}{l}\text { Less than } \\
\text { once a } \\
\text { month }\end{array}$ & $\begin{array}{l}\text { At least } \\
\text { once a } \\
\text { month }\end{array}$ & $\begin{array}{l}\text { At least } \\
\text { once a } \\
\text { week }\end{array}$ & $\begin{array}{l}1-2 \\
\text { hours a } \\
\text { day }\end{array}$ & $\begin{array}{l}\text { More } \\
\text { than } 2 \\
\text { hours a } \\
\text { day }\end{array}$ \\
\hline Word processor & $22 \%$ & $10 \%$ & $12 \%$ & $35 \%$ & $17 \%$ & $4 \%$ \\
\hline Database & $60 \%$ & $19 \%$ & $10 \%$ & $7 \%$ & $2 \%$ & $1 \%$ \\
\hline Spreadsheet & $59 \%$ & $19 \%$ & $11 \%$ & $9 \%$ & $1 \%$ & $1 \%$ \\
\hline Presentation software & $81 \%$ & $11 \%$ & $6 \%$ & $2 \%$ & $0 \%$ & $0 \%$ \\
\hline Desktop publishing & $75 \%$ & $12 \%$ & $6 \%$ & $7 \%$ & $0 \%$ & $0 \%$ \\
\hline $\begin{array}{l}\text { Administration and } \\
\text { management software }\end{array}$ & $68 \%$ & $11 \%$ & $6 \%$ & $8 \%$ & $6 \%$ & $2 \%$ \\
\hline School intranet & $71 \%$ & $7 \%$ & $5 \%$ & $12 \%$ & $3 \%$ & $2 \%$ \\
\hline Search the internet & $60 \%$ & $8 \%$ & $11 \%$ & $14 \%$ & $6 \%$ & $2 \%$ \\
\hline Create Web Pages & $98 \%$ & $1 \%$ & $0 \%$ & $1 \%$ & $0 \%$ & $0 \%$ \\
\hline $\begin{array}{l}\text { Internet discussion } \\
\text { board or chat room }\end{array}$ & $98 \%$ & $1 \%$ & $1 \%$ & $0 \%$ & $0 \%$ & $0 \%$ \\
\hline E-mail & $69 \%$ & $9 \%$ & $6 \%$ & $9 \%$ & $6 \%$ & $1 \%$ \\
\hline $\begin{array}{l}\text { Personal digital } \\
\text { assistant (PDA) }\end{array}$ & $97 \%$ & $1 \%$ & $0 \%$ & $1 \%$ & $1 \%$ & $1 \%$ \\
\hline Peripheral hardware & $46 \%$ & $8 \%$ & $9 \%$ & $25 \%$ & $11 \%$ & $1 \%$ \\
\hline Video conferencing & $100 \%$ & $0 \%$ & $0 \%$ & $0 \%$ & $0 \%$ & $0 \%$ \\
\hline $\begin{array}{l}\text { Authoring own } \\
\text { multimedia or web } \\
\text { resources }\end{array}$ & $99 \%$ & $0 \%$ & $0 \%$ & $0 \%$ & $0 \%$ & $0 \%$ \\
\hline
\end{tabular}

Frequency of use of ICT for management and administration, as revealed by the responses in this section of the questionnaire, were generally low. Taking use of once a week or more, only three categories achieved more than a $20 \%$ response - word processing (56\%), searching the Internet $(22 \%)$ and the use of peripherals (37\%). Furthermore, 13 of 15 areas of use were 
reported as not being used by $59 \%$ or more of primary teachers. Presenting the data in terms of more modest levels of use, 10 out of the 15 categories were used for management or administration purposes, by $20 \%$ or more of teachers in primary schools.

\subsubsection{Ways in which primary teachers use ICT to support their work}

Table 10. Ways in which primary teachers use ICT to support their work

\begin{tabular}{ll}
\hline & Use \\
\hline Resource/material preparation & $77 \%$ \\
Lesson Planning & $71 \%$ \\
Report writing & $64 \%$ \\
Curriculum planning & $64 \%$ \\
As a lesson resource (e.g. web site) & $60 \%$ \\
Timetabling & $47 \%$ \\
School policy development & $43 \%$ \\
Reprographics/photocopying & $43 \%$ \\
Presentations/demonstrations & $38 \%$ \\
Monitoring pupil progress & $35 \%$ \\
Marking and Assessment & $33 \%$ \\
Record Keeping (e.g. database entry) & $31 \%$ \\
Special Educational Needs Coordination (SENCO) & $31 \%$ \\
Development planning & $31 \%$ \\
Exam entries and results & $28 \%$ \\
Records of achievement & $26 \%$ \\
Extra curricular activities & $23 \%$ \\
\hline Registration & $20 \%$ \\
Staff appraisal/supervision or mentoring & $18 \%$ \\
Monitoring attendance & $17 \%$ \\
On-line communities & $17 \%$ \\
Financial records & $14 \%$ \\
Continuing professional development/training & $12 \%$ \\
Budgeting & $12 \%$ \\
Partnership links (contact outside the school) & $11 \%$ \\
Pupil contact (e.g. E-mail/intranet) & $8 \%$ \\
Staff contact (e.g. arranging meetings through E-mail/intranet) & $8 \%$ \\
On-line purchasing of services and/or goods & $6 \%$ \\
\hline Parent/Carer contact (e.g. E-mail) & $3 \%$ \\
\hline
\end{tabular}

Five items were selected by half or more of the primary teachers: preparation of resources $(77 \%)$, lesson planning $(71 \%)$, report writing (64\%), curriculum planning (64\%) and as a lesson resource $(60 \%)$. A further 7 items were selected by more than $30 \%$ of teachers: record keeping (e.g. database entry) (31\%), special educational needs coordination (SENCO) (31\%), development planning (31\%), marking and assessment $(33 \%)$, monitoring pupil progress $(35 \%)$, presentations/demonstrations $(38 \%)$, school policy development (43\%), reprographics/photocopying (43\%), and timetabling $(47 \%)$. It was expected that the use of ICT for financial 
Management

management and administration would not be used widely as these applications tend to be used by a few senior managers in schools, and this was the case. However, the use of ICT for electronic communications was noted as being very low, with only $8 \%$ of primary teachers reporting use of email for contacting pupils or other staff, and $3 \%$ for parent or carer contact.

The interview data tends to support data gathered by the questionnaire, with the most frequently mentioned examples of the use of ITEM being: planning for teaching and learning; monitoring student progress and assessment; report writing and production of lists. Interviewees were also asked to give examples of the benefits of using ICT for management and administration and the most common responses were: more efficient and effective management of work because documents can be updated, edited and shared more easily; more efficient and effective handling of data; access to data improved; quality of data and how it can be used is improved; reduction of workload; and improved presentation and quality of work.

\subsubsection{Factors that might encourage greater use of ICT}

Table 11. Factors that might encourage greater use of ICT

\begin{tabular}{|l|l|l|l|l|l|l|}
\hline & VS.Dis & S.Dis & Dis & Agree & S.Agree & V.S.Agree \\
\hline $\begin{array}{l}\text { Easier access to a computer } \\
\text { at home }\end{array}$ & $8 \%$ & $3 \%$ & $22 \%$ & $25 \%$ & $13 \%$ & $29 \%$ \\
\hline Cheaper training & $2 \%$ & $2 \%$ & $26 \%$ & $39 \%$ & $16 \%$ & $17 \%$ \\
\hline Free training & $2 \%$ & $1 \%$ & $10 \%$ & $32 \%$ & $18 \%$ & $37 \%$ \\
\hline $\begin{array}{l}\text { Training classes at school/ } \\
\text { work }\end{array}$ & $2 \%$ & $1 \%$ & $5 \%$ & $33 \%$ & $23 \%$ & $36 \%$ \\
\hline If I had more spare time & $2 \%$ & $0 \%$ & $5 \%$ & $21 \%$ & $27 \%$ & $44 \%$ \\
\hline $\begin{array}{l}\text { If I was released from work } \\
\text { to train }\end{array}$ & $1 \%$ & $0 \%$ & $2 \%$ & $19 \%$ & $28 \%$ & $50 \%$ \\
\hline $\begin{array}{l}\text { Cheaper computers and free } \\
\text { software }\end{array}$ & $1 \%$ & $0 \%$ & $16 \%$ & $25 \%$ & $25 \%$ & $34 \%$ \\
\hline Free computers or software & $1 \%$ & $0 \%$ & $9 \%$ & $20 \%$ & $22 \%$ & $48 \%$ \\
\hline Cheaper internet access & $2 \%$ & $0 \%$ & $8 \%$ & $25 \%$ & $25 \%$ & $40 \%$ \\
\hline Free internet access & $2 \%$ & $0 \%$ & $6 \%$ & $17 \%$ & $19 \%$ & $56 \%$ \\
\hline
\end{tabular}

It is apparent from the results discussed earlier, that primary teachers are in general positive about the use of ICT to support their administration and management. However, it is also apparent that such use is limited. When asked what factors might encourage them to use ICT more the results shown in Table 11 were obtained. Primary schools teachers' responses to all the options presented to them in this question show high levels of agreement with a range from $67 \%$ to $97 \%$. Only two items score lower than $80 \%$ and these were easier access at home $(67 \%)$ and cheaper training $(72 \%)$. The highest scoring item was a wish to be 'released from work for training', which attracted 97 per cent agreement. 


\section{CONCLUSION}

The results of this baseline study clearly show that primary teachers are positive about the value of ICT in supporting their administrative and management duties. However, when primary teachers' actual use of ICT for administration and management is analysed, the levels of use are quite low. Primary teachers appeared to be aware of the potential of ICT to reduce their workload and improve the quality of their work but also recognise their need further training, which they are keen to undertake. It is apparent that primary teachers have very little non-contact time in English primary schools, and if they are to make greater use of ICT for administration and management either more non-contact time is essential or they need better and cheaper communications between home and school, or both. Furthermore, concerns over access to quality ICT equipment appears to be a real and major issue.

\section{REFERENCES}

Becta, (2003). What the research says about ICT and reducing teacher workloads. Coventry: Becta. www.becta.org.uk/research/ictrn

Department for Education and Employment. (1997). Connecting the learning society: National Grid for Learning (Government Consultation Paper). London: DfEE.

Department for Education and Skills. (2002). Curriculum Online. London: DfES. www.dfes.gov.uk/curriculumonline

Department for Education and Skills. (2003). ICT Test Bed Project. London: DfES. www.dfes.gov.uk/ictinschools/ict active/subject.cfm?articleid $=474$

Selwood, I., Smith, D., Wishart, J., (2001). Supporting UK teachers through the National Grid for Learning in Nolan, P., Fung, A.C.W., \& Brown, M.A. (Eds), Pathways to Institutional Improvement with Information Technology in Educational Management. p 159-171. Boston: Kluwer.

Stevenson Committee. (1997). Information and communications technology in UK schools: An independent enquiry (The Stevenson Report). London: Pearson. [http://www.rubble.ultralab.anglia.ac.uk/stevenson/ contents.html]

Teacher Training Agency. (1998). New Opportunities Fund. The use of ICT in subject teaching lottery-funded training. Expected outcomes. London: DfEE.

\section{ACKNOWLEDGEMENTS}

The research described in this paper was led by Professor $H$ Thomas and undertaken by G Butt, T Fielding, J Foster, H Gunter, A Lance, R Lock, L Potts, R Pilkington, S Powers, S Rayner, D Rutherford, I Selwood and A Soares. 